\title{
Management of cervical root fracture by reattachment using fibre post
}

\author{
Nishant Sinha, ${ }^{1}$ Abishek Lakinepally, ${ }^{2}$ Munira Diwan, ${ }^{3}$ Dileep Kishore Samarthy ${ }^{4}$
}

${ }^{1}$ Army Dental Corps, New Delhi, Delhi, India

${ }^{2}$ Conservative Dentistry and Endodontics, Army Dental Corps, Hyderabad, Telangana, India ${ }^{3}$ Maulana Azad Institute of Dental Sciences, New Delhi, Delhi, India

${ }^{4}$ Conservative Dentistry \& Endodontics, S.V.S Institute of dental sciences, Mahabubnagar, Andhra Pradesh, India

\section{Correspondence to} Dr Abishek Lakinepally, drabi2k9746@gmail.com

Accepted 18 May 2018

\section{DESCRIPTION}

Tooth fractures are commonly reported emergencies in dental practise. They can vary in severity from a simple enamel fracture to complete avulsion of tooth. Among these injuries, crown-root fractures are considered to be the most common cause of tooth loss. ${ }^{1}$ They are clinically challenging cases to treat as management of such cases requires a multidisciplinary approach for complete rehabilitation. Reattachment of the tooth fragment is the most conservative and biological treatment available in case of crown-root fractures if the fractured tooth fragments are available and reported early in a clean and hydrated state. ${ }^{2}$ Reattachment can be done with the help of fibre-reinforced posts which provides increased retention of fractured crown segment and is less subjected to root fracture due to adhesive and elastic properties. ${ }^{3}$ In cases of fractures extending subgingivally, an envelope flap helps to achieve the desired isolation and visibility. This article presents a case report of cervical root fracture treated by reattachment using a fibre post.

A 25-year-old female patient presented with the chief complaint of pain and mobility in upper front teeth. The patient gave a history of trauma 2 hours back due to a road traffic accident accident. No significant medical history was elicited by the patient. Clinical examination revealed

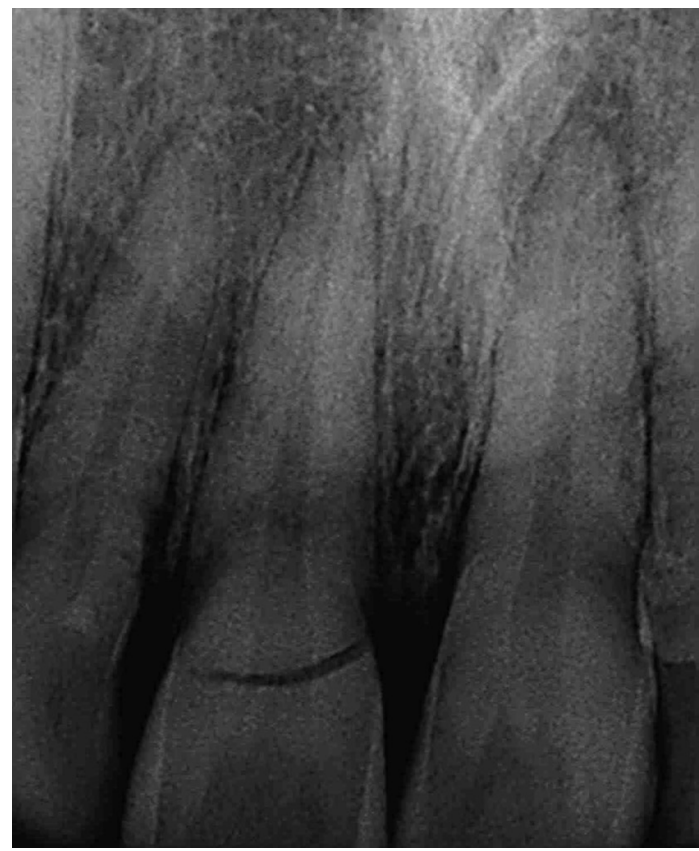

Figure 1 Preoperative radiograph showing fracture of cervical third of root.

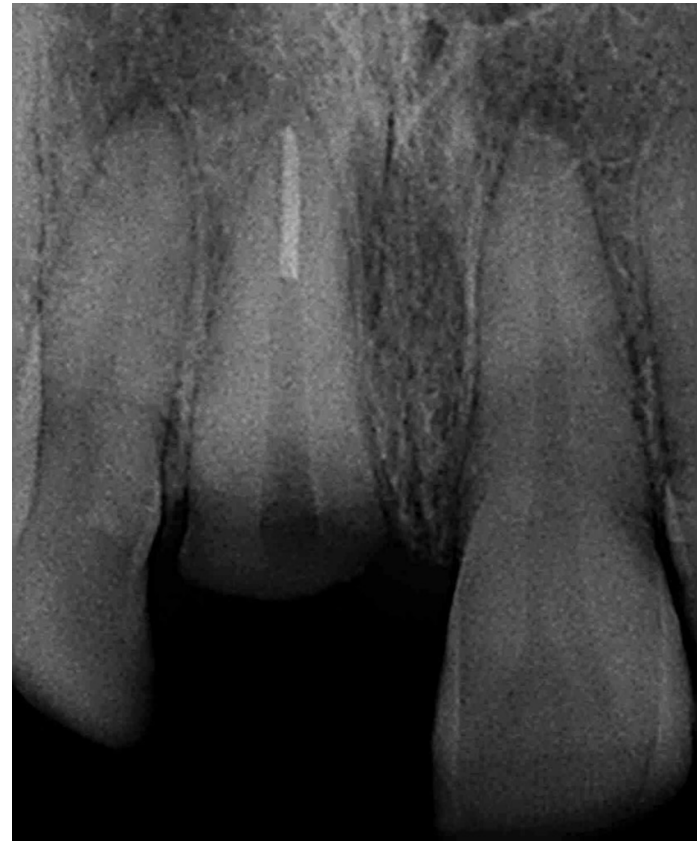

Figure 2 Post-space preparation.

tenderness to percussion in 11 along with Grade II mobility. Preoperative radiograph revealed crownroot fracture extending above the alveolar crest of 11 (figure 1). As the fracture fragment was in oral cavity partially attached to gingiva without any signs of dehydration, treatment by reattachment was explained to the patient. The procedure was started after taking consent from the patient. Single-visit root canal treatment was carried out on 11. Post space was prepared using Gates-Glidden drills and peeso reamers (figure 2). A no $3 \mathrm{HiRem}$ quartz fibre post (Over Fibers, Italy) was selected as desired post. As the fracture line was subgingival, isolation of the fracture line during reattachment was not possible. The fractured crown fragment was removed and preserved in normal saline. Mucoperiosteal envelope flap was raised to completely expose the fracture line. In the case as the fracture line

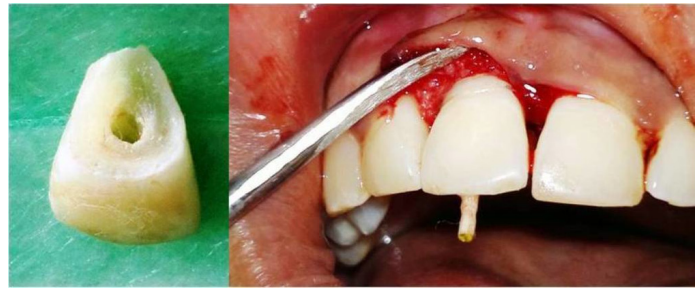

Figure 3 Prepared pulpal aspect of fractured fragment and cementation. 


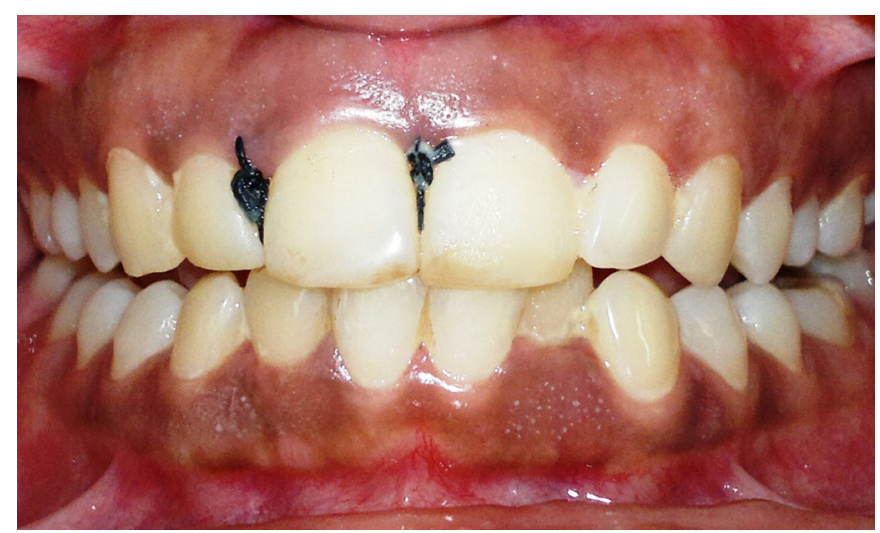

Figure 4 Sutured flaps.

was $<2 \mathrm{~mm}$ below the alveolar bone crest, crown lengthening was performed. This procedure involves removal of $1-2 \mathrm{~mm}$ of crestal bone adjacent to the deepest part of the fracture and restoring the normal sulcus depth of $2 \mathrm{~mm}$. Periodontal and osseous recontouring allowed exposure of the fractured margin and sufficient root surface to give an acceptable restorative finish line for positioning the crown fragment in close proximity to root. This in turn maintains the health of periodontal tissues by preventing restorative overhangs caused during bonding procedures. The fractured fragment was prepared on the pulpal aspect to ensure accurate fit over the post. The post and tooth fragment were luted with dual cure resin luting cement (Relyx) (figure 3).

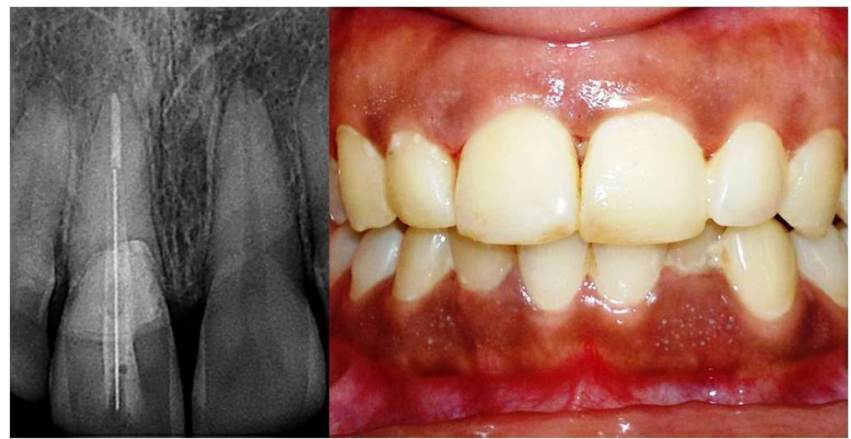

Figure 5 One-month postoperative photograph and radiograph.

\section{Learning points}

- Pain relief and aesthetic restoration are immediate requirements for traumatised teeth.

- Reattachment is an economical treatment option to the patient along with positive emotional and psycho-social response.

- Use of fibre post reinforces the tooth against functional forces.

The flap was sutured with 000 silk sutures (figure 4). The patient was recalled after 1 week for suture removal. After 1 month the patient was asymptomatic with favourable soft tissue healing and good aesthetics. Radiograph revealed the post-cementation and accuracy of fit of fractured segments without any tenderness (figure 5). Patients are advised regarding the care of teeth that underwent trauma and follow-up at intervals of 6-8 weeks, 4 months, 6 months, 1 year and 5 years. Use of $0.1 \%$ chlorhexidine rinse prevents accumulation of plaque and debris and helps in maintaining good oral hygiene. Cases are reported with successful reattachment of fractured fragments with the use of post for augmenting the weakened root avoiding the need for fixed prostheses, implants or extraction.

Contributors NS has done the case. AL and MD have prepared the manuscript. DKS has taken the photographs.

Funding The authors have not declared a specific grant for this research from any funding agency in the public, commercial or not-for-profit sectors.

Competing interests None declared.

Patient consent Obtained.

Provenance and peer review Not commissioned; externally peer reviewed.

(c) BMJ Publishing Group Ltd (unless otherwise stated in the text of the article) 2018. All rights reserved. No commercial use is permitted unless otherwise expressly granted.

\section{REFERENCES}

1 Andreasen FM, Andreasen J0, Cvek M. Root fractures. Textbook and Color Atlas of Traumatic Injuries to Teeth. Andreasen FM, Andreasen JO. Copenhagen: Blackwell Publishing Ltd, 2007:337-71.

2 Grossmann Y, Araúz-Dutari J, Chogle SM, et al. A conservative approach for the management of a crown-root fracture. Quintessence Int 2006;37:753-9.

3 Vâlceanu AS, Stratul SI. Multidisciplinary approach of complicated crown fractures of both superior central incisors: a case report. Dent Traumatol 2008;24:482-6.

Copyright 2018 BMJ Publishing Group. All rights reserved. For permission to reuse any of this content visit http://group.bmj.com/group/rights-licensing/permissions.

BMJ Case Report Fellows may re-use this article for personal use and teaching without any further permission.

Become a Fellow of BMJ Case Reports today and you can:

- Submit as many cases as you like

- Enjoy fast sympathetic peer review and rapid publication of accepted articles

- Access all the published articles

- Re-use any of the published material for personal use and teaching without further permission

For information on Institutional Fellowships contact consortiasales@bmjgroup.com

Visit casereports.bmj.com for more articles like this and to become a Fellow 